\title{
Androgens in female pig reproduction: actions mediated by the androgen receptor
}

\author{
W.F. Pope ${ }^{1}$ and H. Cárdenas \\ Department of Animal Sciences, The Ohio State University, Columbus, Ohio, USA
}

\begin{abstract}
Androgens have potential actions in almost all the organs of males and females. In females, most organs contain some tissues with cells that have androgen receptors. Androgens can regulate cellular functions by binding to androgen receptors or be converted to other hormones. For example, testosterone can bind to the androgen receptor or be aromatised to oestradiol. Treating animals with testosterone, therefore, might elicit some androgenic and oestrogenic effects. Alternatively, testosterone can be converted to other androgens, which in turn, have more or less affinity with the androgen receptor and these new metabolites may or may not be aromatised to oestrogens. This review will highlight the roles of androgens in female mammals other than those as a substrate for oestrogen, with particular emphasis on the actions of the androgen receptors in uteri and ovaries of pigs. Utilising small dosages of an androgen receptor agonist, DHT ( $5 \alpha$-dihydrotestosterone) we have observed that some uterine functions were inhibited while ovarian follicular development was augmented. These inhibitory and stimulatory effects of androgen therapy on reproductive organs can potentially be balanced to enhance ovulation rate and litter size in gilts and sows. Perhaps after future experimentation, new uses of androgens or anti-androgens could improve additional aspects of sow performance not presently under consideration.
\end{abstract}

\section{Introduction}

Testosterone and oestradiol are historically aligned with males and females, respectively. Testosterone, the name sake of the testis, was of primary investigative interest to male physiology because testicles are the major site of testosterone synthesis and castration of males resulted in radical alterations of appearance and behaviour. In females, testosterone was associated with its role as a substrate in oestradiol synthesis and non-substrate roles of androgens were not investigated as ambitiously as other more traditional "female" hormones. Typifying this previously held perception of androgens being a "male" hormone, the term "androgen" was defined as compounds enhancing male characteristics, hormones causing masculinisation or chemicals acting like male hormones. No longer gender-orientated in definition, androgens can now be

Correspondence': Department of Animal Sciences, 2027 Coffey Road, Plumb Hall, OSU, Columbus, OH, USA, 43210

E-mail: pope.2@osu.edu 
considered to be compounds that bind to the androgen receptor (AR). To date, the list of known endogenous and synthetic androgens is extensive.

Fortunately information is available regarding the roles of oestrogens in males and androgens in females. Oestradiol is essential for development of the testis and prostate, maintenance of the skeleton and cardiovascular system, promotion of masculinisation and libido in males (Bakker et al., 2004). In females, endogenous androgens have a wide array of effects and exogenous androgens are prescribed for women to meet a diverse range of therapeutic objectives (Table 1). However, exogenous androgens can have serious consequential effects on many organs and androgen treatment of food producing animals will continue to be a safety concern to human health.

Table 1. Various androgen treatments or therapies in females (references not included)

\section{Women}

Sexual dysfunction/state of well-being

Skin burns

Wound healing

Sports/body composition

Osteoporosis/bone density

Endometriosis

Post menopausal(with oestrogen)/Hot flushes

Hereditary angioedema

Breast cancer

Leukemia

Addison's Disease/adrenal insufficiency

Hepatic and kidney failure

Low lacrimal function/Sjogren's syndrome

Cachexia/anorexia (with AIDS/cancer)

Chronic obstructive pulmonary disease

Lower cholesterol and HDL

Dialysis (androgens with erythropoietin)

\author{
Catte and Sheep \\ Growth promotant (feedlot) \\ Post natal growth (prenatal treatment) \\ Reduce fear \\ Block ovulation \\ Increase ovulation rate by immunisation \\ Mice and Rats \\ Growth of mammary ducts/stroma \\ Increase synapses in hippocampus \\ Attenuate seizures \\ Inhibits non-obese diabetes \\ Multiple Animal Models \\ Hypothalamic/behavioural masculinisation \\ Pigs \\ See Table 2
}

The role of androgens in females is a timely subject as androgenic disorders are now considered the most common endocrinopathy of women, affecting at least 10 to 20 percent of the US population (Redmond, 1998). Unfortunately, these pathologies remain under reported as women tend to hide hypo- or hyper-androgenic conditions rather than seek medical attention.

Androgens are essential as substrates for oestrogen synthesis, however, androgens also have additional functions in females. For example, utilising a new strategy, the cre-lox knock-out procedure, Yeh et al. (2002) demonstrated that in AR knock-out (ARKO) mice, females are fertile but litter size is small. Curiously, the reverse scenario also exists in which androgens have a role only through their conversion to oestrogen. For example, memory in male rats, as qualified in a water radial maze, is enhanced with testosterone but not with the non-aromatisable androgens (Bimonte-Nelson et al., 2003).

This review will focus on the effects of androgens in females beyond their role as a substrate for oestrogen synthesis. The steroid, DHT is an endogenous androgen that is synthesised by the enzyme $5 \alpha$-reductase. DHT can not be aromatised to oestrogen (Wilson, 1975) and fortuitously, experimentation utilising DHT allows androgen's role as a substrate for oestrogen to be distinguished from AR-mediated events. Therefore, investigational use of DHT to alter aspects of female reproduction will be frequently cited in this review. Additionally, inclusion of the location and activity of $5 \alpha$-reductase will offer information about sites of DHT action. Information specific to swine will be considered noteworthy and at times will supersede earlier discov- 
eries in other species. In the forthcoming paragraphs, the general actions of androgens in females will be highlighted followed by a more specific discussion of the uterus and ovary. The last section will summarise known and potential areas of pig reproduction that might be enhanced with androgen treatment of females.

\section{General actions of androgens in females}

The physiological actions of androgens in females are complex, as androgens induce physiological effects via combinations of a variety of mechanisms and pathways. Androgens can bind to their cognate nuclear AR (genomic effects). Classical AR belongs to the family of nuclear receptors, a group of proteins that influence gene transcription. The AR gene is located on the $X$ chromosome (Seifert et al., 1999) and its associated polymorphisms have been identified in pigs (Trakooljul et al., 2004). Androgens may also bind to membranous receptors and elicit non-genomic effects (Revelli et al., 1998). Gorczynska and Handelsman (1995) observed nongenomic effects when freshly isolated Sertoli cells experienced increased intracellular concentrations of calcium within 20 seconds of DHT treatment. A less known pathway is the ligandindependent pathway (Buchanan et al., 2001). Kim et al. (2005) suggested that enhanced phosphorylation and formation of a novel bridging ("enhanceosome cooperation") action of p300/ CBP (CREB-binding protein) between unbound AR and CREB (CAMP responsive element-binding protein) allowed continued transcription of target genes even in the absence of the ligand (androgen).

Many androgens can be enzymatically converted to other active androgens, a process called intracrinology (Labrie et al., 2003). When these additional intracrine pathways for androgen were evaluated, Labrie et al. (2003) estimated that women synthesise approximately two thirds the amount of total androgens synthesised by men. Newly converted androgens may have more or less affinity with the AR. One such pertinent pathway in females is the rather widespread conversion of testosterone to DHT. A forthcoming discussion of the location of $5 \alpha$ reductase will support the widespread nature of this pathway. As an AR agonist, DHT has a greater affinity for the AR than testosterone (Grino et al., 1990) and throughout the body, the conversion of testosterone to the more potent androgen, DHT, can be considered a mechanism of "androgen amplification" (Roy and Chatterjee, 1995).

Androgens can also influence oestrogenic responses in gilts, not necessarily through the oestrogen-substrate role but, by altering amounts of oestrogen receptors (ER $\alpha$ and ERß; Cárdenas and Pope, 2004). Androgens can interact with numerous other receptors and growth factors. For example, DHT can be reduced by $3 \alpha$-hydroxysteroid oxidoreductase to $3 \alpha$-androstanediol (Martini et al., 1993). Although $3 \alpha$-androstanediol has no affinity for the AR (Cunningham et al., 1979) it does bind to steroid recognition sites of the GABA receptor (Marrow et al., 1990). As another example of interactions with other receptors and growth factors, androgens can enhance or attenuate FSH or IGF-1 responses in follicles (deMoura et al., 1997; Vendola et al., 1999). Finally, androgens can cause differentiation of several organs or responses (i.e. virilism of hair distrubtion, abnormal oestrous behaviour and liver function) in females but the mechanism(s) controlling several of these permanent changes remain unclear.

Despite dramatic behavioural differences between the sexes, few anatomical and molecular markers have been identified to further differentiate between the male and female brain (Cooke et al., 1998). Shah et al. (2004) modified the AR gene in mice to co-express two reporter molecules, lacZ and placental alkaline phosphatase (PLAP). Adding ß-galactosidase to the tissue sections allowed labelling of AR containing nuclei while the addition of PLAP resulted in visualisation of neuronal processes. Less than 10 percent of the neurones within the mouse 
brain contained AR. In addition to the three known sexually dimorphic areas of the brain, the preoptic area of the hypothalamus, the bed nucleus of the stria terminalis and the nucleus of the bulbocavernosus, new dimorphic "islands" in the basal forebrain were observed to contain ARstained neurones (Shah et al., 2004). A closer examination of the three dimorphic areas revealed that the dorsal raphe nucleus, an area of the brain that innervates projections to the cerebral cortex and limbic system, is devoid of AR in female rats and mice, in contrast to males with modest-to-abundant amounts of AR (Sheng et al., 2004).

Testosterone exerts many of its effects on the brain of females after conversion to DHT or oestrogens. Two different genes encode for $5 \alpha$-reductase- 1 and -2 ( $5 \alpha-R-1$ and $5 \alpha-R-2$, respectively; Wilson and Russell, 1994). Both these isoforms reduce androgens and are present throughout the body, including the major divisions of the brain (Callard et al., 1978). Genes encoding for $5 \alpha-R-1$ are positively controlled by DHT while $5 \alpha-R-2$ genes are negatively regulated by DHT in the brain (Torres and Ortega, 2003). Neurones and glial cells have $5 \alpha$-reductase but neurones apparently have greater activity than glial cells (Celotti et al., 1991). These authors suggested that neurones also have, but glial cells lack, the ability to convert testosterone to oestradiol. Finally, the feedback of steroids on $\mathrm{GnRH}$ secretion might be through intermediate GABA neurones, as AR is not found in GnRH neurones (sheep, Herbison et al., 1996). Sullivan and Moenter (2004) suggested that DHT can affect $\mathrm{GnRH}$ release by stimulating release of GABA and increasing the number of synaptic contacts from GABAergic to GnRH neurones.

Expression of female-type behaviour in female mice is highly dependent on ER activity and independent of AR function (Sato et al., 2004) but this dependency is not evident in rhesus monkeys (Thorton and Goy, 1986). Sato et al. (2004) hypothesise that sexual dimorphism differs between rodents and primates. In swine, adult sexual activity after treatment of male foetuses with androgens changed more dramatically than similarly treated females. Treatment of pregnant sows with testosterone proprionate on days 29 to 50 resulted in a wide range of effects in female offspring. These post-treatment effects of testosterone proprionate included; delayed age at puberty, aberrant oestrogen feedback on $\mathrm{LH}$ secretion, unchanged tonic $\mathrm{LH}$ secretion, some, but not complete virilised genitalia and only a slight reduction in the extent of their female-type behaviour (Elsaesser and Parvizi, 1979; Ford and Christenson, 1987; Petric et al., 2004). It remains unknown if these effects in gilts are via the AR or are the result of conversion to oestrogens or other hormones.

The presence of hepatic AR was first detected in rabbits (Sheets et al., 1985) and has subsequently been identified in the liver of females of a number of mammals. The activity of $5 \alpha-$ reductase in the liver of adult females is 5- to 10-fold greater than in male rats (Yates et al., 1958). There are hypothetically two periods or events during development that establish gender differences in hepatic $5 \alpha$-reductase activity. The first is during the neonatal period when testicular androgens imprint a masculine potential on an otherwise feminine activity (McEwen, 1976). The second period of hepatic maturation of $5 \alpha$-reductase activity is at puberty (Pak et al., 1985), when androgen treatment of males further decreases $5 \alpha$-reductase activity. The "female" pattern of $\mathrm{GH}$ secretion (more continuous than the typical pulsatile pattern of males) stimulates $5 \alpha$-reductase in the liver (Waxman et al., 1989) perhaps explaining the cause of gender differences in $5 \alpha$-reductase activity. A resulting greater $5 \alpha$-reductase activity in the female liver as compared to the male, might be a mechanism for females rats to metabolise more $\Delta^{4}$-3-keto-steroids (Yates et al., 1958). Alternatively, female rats might increase the regulatory impact of androgens on hepatocyte function through androgen amplification, in lieu of lesser concentrations of androgens in their blood than males. Finally, liver weight is positively correlated with ovulation rate in gilts (Wise and Ford, 1998), perhaps due to an altered feedback system involving differences in metabolic clearance of steroids and subsequent secretion of gonadotrophins. 


\section{Androgen action(s) in the uterus and ovary}

\section{Uterus}

The AR is found in the nuclei of many cell types in pig uteri. However, some differences exist among species in the patterns and proportions of AR within various cell types of the uterus. Utilising immunohistochemistry techniques, we observed strong AR staining in the luminal and glandular epithelium with approximately $40 \%$ less staining in the myometrium of gilts (Cárdenas and Pope, 2003). Androgen receptor staining was also evident in the subepithelial stroma, while AR staining was less in stromal cells that were located deeper in the endometrium. Neither stage of the oestrous cycle nor events during early gestation appeared to alter the amount of AR staining (Cárdenas and Pope, 2003).

The potential for endocrine control of AR gene expression in the uterus was examined by utilising an ovariectomised gilt model followed with replacement therapy of oestradiol or $\mathrm{DHT}$ alone or the combination of oestradiol and DHT. Treatment with DHT alone did not change the amounts of AR mRNA from those of gilts in the vehicle group. However, oestradiol administration alone did increase mRNA for AR but this increase was partially blocked with DHT and oestradiol co-treatment (Cárdenas and Pope, 2004).

Considering multi-cell type (whole) cultures of endometrial tissues, $5 \alpha$-reductase activity has been known to exist in gilts for a considerable period of time (Henricks and Tindal, 1971; Gadsby, 1978; Fischer et al., 1985) but cell specific localisation has not yet been determined. The enzyme $5 \alpha$-reductase has been localised in the human endometrium, specifically in epithelial, but not in stromal (Ito et al., 2002) nor myometrial (Bulun et al., 1994) cells.

Androgens might antagonise several uterine functions in gilts, perhaps through attenuation of the ERs and, therefore, inhibition of oestrogen-sensitive genes. Co-treatment of ovariectomised gilts with oestradiol and DHT reduced amounts of immunoreactive ER $\alpha$ in myometrial and stromal cells, and tended to decrease the amounts of ER in the luminal epithelium. Curiously, the glandular epithelia expressed a unique, cell-type, specific response as the amounts of immunoreactive $E R \alpha$ remained unchanged from those of gilts treated with oestradiol alone (Cárdenas and Pope, 2004). The inhibitory actions of androgens, when administered during the preceding follicular phase, on the ability of the uterus to support early conceptus development are dose and duration of treatment dependent (Cárdenas and Pope, 1997; Cárdenas et al., 2002). Other inhibitory actions of androgens, specifically during the follicular phase of the oestrous cycle, range from marginal (uterine wet weight and cell proliferation) to significant (amount of complement component C3 message; Cárdenas and Pope, 2005). Finalły, the effects of androgens in intact, cycling gilts are possibly modulated differently than those of ovariectomised gilts (Cárdenas and Pope, 2005).

As uterine stromal cells are sensitive to androgenic antagonism of oestrogenic effects, understanding the nature of this interaction might be valuable. Apparently, AR and ER $\alpha$ can be coexpressed in the same uterine cell types, but the mechanism(s) influencing their interactions is not clear. For example, the presence of androgen-response element(s) in the ER gene has not been reported. Collectively, these observations have led us to suggest that bound $A R$ in endometrial stromal cells attenuates oestrogenic action(s) in the uterus of gilts. Specifically, stromal cells of the endometrium down-regulate the ERs in response to androgens, and those down-regulated stromal cells in turn might alter other factors required by juxtapositional epithelia. This cell-to-cell interaction between stroma and epithelia has been hypothesised to exist in other species (Clark et al., 1985; Buchanan et al., 1999).

\section{Ovarian synthesis of androgens}

Androgens common to females of other species, testosterone, DHT, dehydroepiandrosterone 
(DHEA), DHEA sulphate and androstenedione, have also been observed in gilts (Stone and Seamark, 1985). Androstenedione is actively synthesised by theca cells of growing follicles, as concentrations in follicular fluid are several fold greater than testosterone (Evans et al., 1981; Tsang et al., 1985). Androstenedione exceeds testosterone concentrations in blood from the utero-ovarian vein by 2 - to 20 -fold (Ciereszko et al., 1989). Although, porcine gonadal aromatase converts testosterone into oestrogens slower than androstenedione (Corbin et al., 1999), androstenedione is metabolised through the intermediate oestrone, in the pathway to oestradiol (Peters and McNatty, 1980). In contrast, testosterone can be directly aromatised to oestradiol and the AR has more affinity for testosterone than androstenedione (Wilson, 1996). In summary, androstenedione probably has a major role as a substrate for oestrogen synthesis rather than as an agonist for the AR. Our laboratory has focused initially on testosterone and DHT effects in the ovary and, to date, we have done little experimentation with androstenedione.

The pattern of testosterone secretion during the porcine oestrous cycle has been examined previously (Fitko et al., 1998; Jana et al., 2000; Wise and Ford, 1998; Jana et al., 2004). Concentrations of DHT in peripheral blood were lower than testosterone and did not change during the oestrous cycle (Fig. 1; E.Routman, E. Jimenez, H. Cárdenas and W. Pope, unpublished). Testosterone increased $(P<0.05)$ from oestrus to the luteal phase and then followed a transient trend of decreasing from the expected time of luteolysis (days 14 to 16 ; day 0 = first day of oestrus; gilts averaged a 19.5 day cycle) to increasing again at oestrus. It is possible that the increase in systemic testosterone during the luteal phase reflects corpora lutea secretion (Gregoraszczuk and Oblonczy, 1996). Blood samples collected from additional gilts on days 0 , 5,10 and $17(n=4)$ from the jugular and ovarian vein demonstrated that the concentration of testosterone was less in the jugular compared with the ovarian vein but the concentration of DHT was not affected by site of venepuncture (data not shown, E.Routman, E. Jimenez, $H$. Cárdenas and $W$. Pope, unpublished). These latter observations suggest that the ovary is a significant source of peripheral testosterone but not DHT.

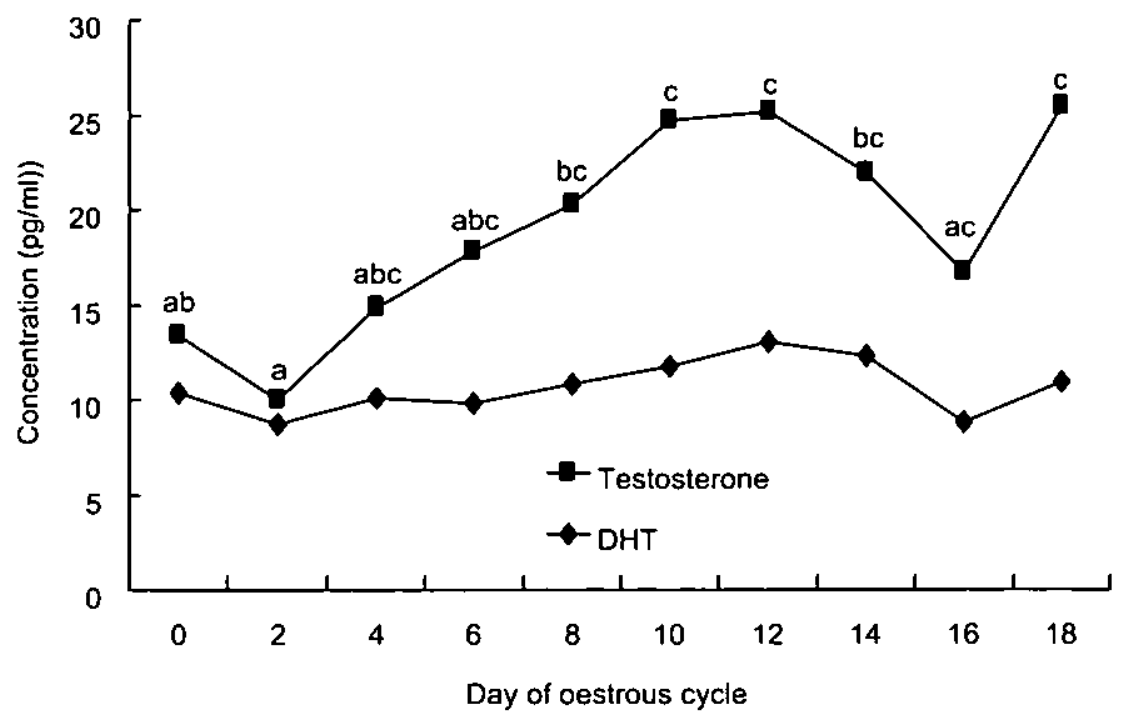

Fig. 1 Mean concentration of testosterone and dihydrotestosterone in plasma from the jugular vein of gilts $(n-6)$ sampled on even numbered days of the oestrous cycle. SEM for concentrations of testosterone and DHT in plasma were 10 and 2, respectively. Mean concentrations of testosterone with different superscripts $(a, b$ or $c)$ are different $(P<0.05)$. 
Through genetic selection, the University of Nebraska has developed a line of pigs with an increased ovulation rate (Johnson et al., 1999). Analysis of some physiological differences between these lines has indicated that more oestrogen-active follicles were present in the larger ovulationrate line, two to three days before ovulation, and that these follicles were selected over a longer period than follicles of control gilts (Yen et al., 2005). Microarray analysis allowed Caetano et al. (2004) to observe 59 unique genes from follicular tissues that were differentially expressed between the select and control line. Some of these differentially expressed genes were related to the transport of cholesterol to follicular cells, other genes were associated with steroidogenic enzymes (side chain cleavage, 17- $\alpha$-hydroxylase, aromatase and cytochrome $C$ oxidase), and others with the steroidogenic acute regulatory (StAR) protein. Noteworthy, is the upregulation of $17-\alpha-h y-$ droxylase during the final days of follicular maturation in the high ovulating gilts as this enzyme catalyses the conversion of progesterone to androgens.

\section{Ovary - AR and $5 \alpha$-reductase activity}

The porcine adrenal, uterus, liver and pituitary gland contain $84,62,44$ and $1 \%$, respectively, of the amounts of AR mRNA in the ovary (Trakooljul et al., 2004). Within the ovary, the AR has been detected in nuclei of most cell types of follicles (pigs, Garrett and Guthrie, 1996; Cárdenas et al., 2002a; Hickey et al., 2004), corpora lutea (Carrizo et al., 1994), stroma (Otala et al., 2004) and surface epithelia (Edmonson et al., 2002). Within the porcine follicle, a greater density of AR has been detected in the granulosa cells of preantral, small and medium sized follicles than larger follicles (Garrett and Guthrie, 1996; Slomczyñnska and Tabarowski, 2001; Cárdenas and Pope, 2002a). During late follicular development, the amount of $A R$ remains rather constant in preovulatory follicles (Tetsuka et al., 1995; Hillier and Tetsuka, 1997; Cárdenas and Pope, 2002a). Recently, we noted that the intensity of staining for the AR protein in cells of pre-antral and small follicles remained constant during the oestrous cycle and only decreased before the onset of oestrus ( $H$. Cárdenas and W. Pope, unpublished data). Theca cells contain 40 to $60 \%$ less AR than granulosa cells and, unlike granulosa cells, AR in theca cells are not influenced by day of the oestrous cycle $(\mathrm{H}$. Cárdenas and W. Pope, unpublished data). Although the location and relative intensities of staining for the AR have been determined within the ovary, to date, the likely functional activity for these receptors has not been proposed.

In rats, the activity of $5 \alpha$-reductase peaks in the ovary coincident with CL formation (Lephart et al., 1992). Perhaps related, within the human ovary, $5 \alpha$-reductase is more prevalent in the CL than stroma or follicles (Haning et al., 1996). Luteinising hormone stimulated theca $5 \alpha$-reductase activity (Aono et al., 1981), while the relatively smaller amounts of $5 \alpha$-reductase in granulosa cells were inhibited by FSH (Payne et al., 1992). In rat granulosa cells, IGF-1 slightly elevated $5 \alpha-$ reductase activity whereas FSH did not alter the activity of the enzyme (deMoura et al., 1997).

\section{Ovary - Effects of DHT on porcine follicles}

Exogenous DHT from days 13 to oestrus increases ovulation rate (Cárdenas et al., 2002), and increases FSH receptor mRNA (FSHR; Cárdenas and Pope, 2002a), but does not change the amount of immunostaining of AR in thecal and granulosa cells (Cárdenas and Pope, 2005). In vitro, DHT suppresses $\mathrm{FSH}$ induced progesterone production but induces granulosa cell proliferation, particularly in cells in close proximity to the oocyte (Hickey et al., 2004) and inhibits FSH induced aromatase activity (Chan and Tan, 1986). Continuing this list of DHT effects with observations in rats includes: augmenting FSH induced progesterone synthesis (Armstrong and Dorrington, 1976), stimulating growth of follicles primed with PMSG (Daniel and Armstrong, 1980), inhibiting FSH induced stimulation of $\mathrm{LH}$ receptor synthesis (Jia et al., 1985) and augmenting $\mathrm{FSH}$-stimulated utilisation of lipoproteins by granulosa cells (Schreiber et al., 1984). 
Considering the novel effects of DHT on ovulation rate, partitioning the treatment with DHT from days 13 to oestrus into shorter periods of days 13 to 16 or days 17 to oestrus, resulted in similar increases in ovulation rates to those treated with DHT from days 13 to oestrus (Cárdenas et al., 2002). It is possible that effects of exogenous androgen occur during the first two or three days of treatment and that smaller, more critical, windows of drug administration may offer an alternative to the more common, day 13 to oestrus regime.

At the time of this review it remains unknown how DHT increases ovulation rate in gilts. We have observed that treatment of gilts with DHT increased the MRNA for FSHR (Cárdenas and Pope, 2002a) and hypothesised that an increase in FSHR might be associated with the increase in ovulation rate (Cárdenas and Pope, 2005). FSH has many positive influences on ovarian follicular growth which could explain some of the effects of DHT including the stimulation of; granulosa cell division (Babu et al., 2000), anti-apoptotic factors (Kaipia and Hsueh, 1997), aromatase activity (Hickey et al., 1988), progesterone synthesis (Ford and Howard, 1997) and increasing the amounts of LH receptors (Channing, 1975; LaBarbera and Ryan, 1981). Guthrie et al. (1998) suggested that FSH functions as a primary element in regulating follicular atresia. Guthrie and Bolt (1990) noted that selection of ovulatory follicles occurs coincident with decreasing FSH and several laboratories have suggested that $\mathrm{LH}$ might be responsible for initiating final maturation of ovulatory follicles (Nakano et al., 1977; Foxcroft and Hunter, 1985; Liu et al., 1998). Perhaps increasing the amounts of FSHR coincident with the normal decrease of FSH (ligand) is a mechanism(s) to delay the loss of $\mathrm{FSH}$ "influence" in follicles.

\section{Potential uses of androgens in female pigs}

Treatment of pigs with androgens will continue to be a marketing, and in some cases a health, concern for consumers. Any favourable use of androgens to improve reproductive performance of gilts or sows would have to fully address any public concerns. Documented areas for androgen therapy to improve gilt performance are illustrated at the top of Table 2, while more speculative uses of exogenous androgens are listed at the bottom. It is probable that few of the therapies listed in Table 2 are exclusive of androgen's role as a substrate for oestrogens.

Table 2. Potential uses for androgen to improve reproductive performance in female pigs.

\begin{tabular}{|c|c|c|}
\hline Production parameter & Observed or theoretical effect & Reference \\
\hline $\begin{array}{l}\text { Litter size } \\
\text { Litter size } \\
\text { Neonatal rate of gain } \\
\text { Juvenile rate of gain }\end{array}$ & $\begin{array}{l}\text { Increased one pig/litter } \\
\text { Increased ovulation rate } \\
\text { One day old at treatment } \\
\text { Androgen and oesiradiol implant }\end{array}$ & $\begin{array}{l}\text { Cardenas and Pope, 2002b } \\
\text { Cardenas and Pope, } 1994 \\
\text { Dvorak, } 1981 \\
\text { DeWilde and Lauwers, } 1984\end{array}$ \\
\hline \multicolumn{3}{|c|}{ Potential or speculative applications } \\
\hline $\begin{array}{l}\text { Number of teats } \\
\text { Herd conception rate } \\
\text { Mammary growth } \\
\text { Birth weight } \\
\text { In vitro fertilisation } \\
\text { Oestrous detection }\end{array}$ & $\begin{array}{l}\text { Prenatal antiandrogen therapy } \\
\text { Prenatal antiandrogen therapy } \\
\text { Duct and stroma development (rats) } \\
\text { Prenatal androgens, before d } 104 \\
\text { First attempt failed to improve } \\
\text { Improve boar libido, prenatal }\end{array}$ & $\begin{array}{l}\text { Drickamer et al., } 1999 \\
\text { Drickamer et al., } 1997 \\
\text { Zhang et al., 2004 } \\
\text { Wise and Christenson, } 1992 \\
\text { Herrick and Pope., } 2002 \\
\text { Rohde Parfet, et al., } 1990\end{array}$ \\
\hline
\end{tabular}

The speculative uses of androgens are based on hypothetical application of some recent observations and require further elaboration (Table 2, bottom). The number of teats and conception 
rate of gilts is another important trait to swine production but these phenotypes are reduced in gilts from litters with a greater proportion ( $>67 \%$ ) of males (Drickamer et al., 1997; Drickamer et al., 1999). Treatment with anti-androgens at a critical stage of gestation might reverse the negative affects of androgens or androgen induced factors from neighbouring foetal males. Likewise, further experimentation perhaps to determine a more precise window of treatment or to examine a better source or dosage of androgen, could be utilised in a therapy to enhance birth weights. Finally, many of the androgen therapies listed in Table 2 might have to be partitioned within a large swine operation to treatment of those pigs (foetuses) dedicated for growth as compared with replacement females.

\section{Conclusion}

Androgens are endogenous to normal female reproduction but their specific functions remain, for the most part, to be determined. One of the difficulties in investigating the role of androgens is the multiple pathways by which these steroids alter cellular function. In addition to being a substrate for oestrogen synthesis, androgens can bind to AR, be metabolised to other hormones, alter amounts and actions of other receptors, interact with growth factors and possibly other pathways still undiscovered. Although investigations have surveyed the body for the location of the AR and $5 \alpha$-reductase, and other experimentation has allowed concluding circumstances that facilitate some changes in these proteins, the science of what androgens do in the normal physiological events of female reproduction is glaringly absent. This review, even with its focus on AR actions in the uterus and ovary, can offer little more to this "survey". Under experimental conditions some aspects of uterine function were attenuated by androgens through interactions with oestrogenic pathways. Specific to the ovary, recent observations indicate that the AR exists in various cell types of porcine follicles and binding of androgens to the AR can have a positive influence on events during final maturation of follicles. The potential exists for many aspects of pig production to be influenced by androgen treatments. Understanding basic mechanisms of how androgens directly or indirectly alter reproductive performance in sows and gilts probably will prove valuable to improving swine production.

\section{References}

Aono T, Kitamura Y, Fukuda S and Matsumoto K (1981) Localization of 4 -ene-5 $\alpha$-reductase $17 ß$-ol-dehydrogenase and aromatase in immature rat ovary fournal of Steroid Biochemistry 14 1369-1377

Armstrong DT and Dorrington JH (1976) Androgens augment FSH-induced progesterone secretion by cultured rat granulosa cells Endocrinology 991411 1414

Babu PS, Krishnamurthy $H$, Chedrese PJ and Sairam MR (2000) Activation of extracellular regulated kinase pathways in ovarian granulosa cells by the novel growth factor type 1 follicle-stimulating hormone receptor fournal of Biological Chemistry 275 2761527626

Bakker J, Honda S, Harada N and Balthazart J (2004) Restoration of male sexual behavior by adult exogenous estrogen in male aromatase knockout mice Hormones and Behavior 46 1-10

Bimonte-Nelson HA, Singleton RS, Nelson ME, Eckman
CB, Barber J, Scott TY and Granholm AC (2003) Testosterone, but not nonaromatizable dihydrotestosterone improves working memory and alters nerve growth factor levels in aged male rats Experimental Neurology $181301-312$

Buchanan G, Irvine RA, Coetzee GA and Tilley WD (2001) Contribution of the androgen receptor to prostate cancer predisposition and progression Cancer Metastasis Reviews 20 207-223

Buchanan DL, Setiawan T, Lubahn DB, Taylor JA, Kurita T, Cunha GR and Cooke PS (1999) Tissue compartment-specific estrogen receptor-alpha participation in the mouse uterine epithelial secretory response Endocrinology 140 484-491

Bulun SE, Simpson ER and Word RA (1994) Expression of the CYP19 gene and its product aromatase cytochrome $\mathbf{P 4 5 0}$ in human uterine leiomyoma tissue and cells in culture Journal of Clinical Endocrinology and Metabolism 78 736-743 
Caetano AR, Johnson RK, Ford IJ and Pomp D (2004) Microarray profiling for differential gene expression in ovaries and ovarian follicles of pigs selected for increased ovulation rate Genetics 168 1529-1537

Callard GV, Petro Z and Ryan KJ (1978) Phylogenetic distribution of aromatase and other androgen-converting enzymes in the central nervous system Endocrinology 103 2283-2290

Cárdenas H and Pope WF (1994) Administration of testosterone during the follicular phase increased the number of corpora lutea in gilts fournal of Animal Science 72 2930-2935

Cárdenas H and Pope WF (1997) Administration of testosterone from day 13 of the estrous cycle to estrus increased the number of corpora lutea and conceptus survival in gilts fournal of Animal Science 75 202207

Cárdenas H and Pope WF (2002a) Androgen receptor and follicle-stimulating hormone receptor in the pig ovary during the follicular phase of the estrous cycle Molecular Reproduction and Development 62 92-98

Cárdenas H and Pope WF (2002b) Control of ovulation rate in swine fournal of Animal Science 80(E.Suppl.1) E36-E46

Cárdenas H, Herrick IR and Pope WF (2002) Increased ovulation rate in gilts treated with dihydrotestosterone Reproduction 123 527-533

Cárdenas H and Pope WF (2003) Distribution and changes in amounts of the androgen receptor in the pig uterus during the oestrous cycle, early pregnancy and after treatment with sex steroids fournal of Endocrinology 177 461-469

Cárdenas $\mathrm{H}$ and Pope WF (2004) Attenuation of estrogenic effects by dihydrotestosterone in the pig uterus is associated with downregulation of the estrogen receptors Biology of Reproduction 70 297-302

Cárdenas $\mathrm{H}$ and Pope WF (2005) Estrogen receptors in the uterus and ovarian follicles of gilts treated with dihydrotestosterone Domestic Animal Endocrinology 29 523-533

Carrizo DG, Rastrilla AM, Telleria CM and Aguado LI (1994) Androstenedione stimulates progesterone production in corpora lutea of pregnant rats: an effect not mediated by estrogen Journal of Steroid Bio chemistry and Molecular Biology 51 191-197

Celotti F, Melcangi RC, Negri-Cesi P and Poletti A (1991) Testosterone metabolism in brain cells and membranes The lournal of Steroid Biochemistry and Molecular Biology 40 673-678

Chan WK and Tan CH (1986) FSH-induced aromatase activity in porcine granulose cells: non-competitive inhibition by non-aromatizable androgens fournal of Endocrinology 108 335-341

Channing CP (1975) Follicle stimulating hormone stinulation of ${ }^{25}$ /-human chorionic gonadotropin binding in porcine granulosa cell cultures Proceedings of the Society of Experimental Biology and Medicine 149 238-241

Ciereszko R, Dusza L, Okrasa S, Kotwica G, and Tilton JE (1989) Endocrine changes associated with spontaneous luteolysis in sows. II. Temporal relationships among the concentrations of $\mathrm{A} 4, \mathrm{~T}, \mathrm{E} 1$ and $\mathrm{E} 2$ measured in utero-ovarian vein plasma Animal Reproduction Science 21 53-61

Clark JH, Schrader WT and O'Malley BW (1985) Mechanisms of steroid hormone action. In Textbook of Endocrinology pp33-75 Eds JD Wilson and DW Foster. WB Saunders, Philadelphia

Cooke B, Hegstrom CD, Villeneuve $L S$ and Breedlove SM (1998) Sexual differentiation of the vertebrate brain: principles and mechanisms Frontiers in Neuroendocrinology 19 323-362

Corbin Cl, Trant JM, Walters KW and Conley AJ (1999) Changes in testosterone metabolism associated with the evolution of placental and gonadal isozymes of porcine aromatase P450 Endocrinology 140 52025210

Cunningham GR, Tindall DJ and Means AR (1979) Differences in steroid specificity for rat androgen binding protein and the cytoplasmic receptor Steroids $\mathbf{3 3}$ 261.267

Daniel SAJ and Armstrong DT (1980) Enhancement of follicle-stimulating hormone-induced aromatase activity by androgens in cultured rat granulosa cells Endocrinology 107 1027-1033

deMoura MD, Choi D, Adashi EY and Payne DW (1997) Insulin-like growth factor-l-mediated amplification of follicle-stimulating hormone-supported progesterone accumulation by cultured rat granulosa cells: enhancement of steroidogenic enzyme activity and expression Biology of Reproduction 56 946-953

DeWilde RO and Lauwers H (1984) The effect of parenteral use of estradiol, progesterone, testosterone and trenbolone on growth and carcass composition in pigs lournal of Animal Science 59 1501-1509

Drickamer LC, Arthur RD and Rosenthal TL (1997) Conception failure in swine: importance of the sex ratio of a female's birth litter and tests of other factors Journal of Animal Science 75 2192-2196

Drickamer LC, Rosenthal TL and Arthur RD (1999) Factors affecting the number of teats in pigs lournal of Reproduction and Fertility 115 97-100

Dvorak M (1981) The effect of testosterone administered in the neonatal period of the growth of piglets Veterinarni Medicina 26 65-7

Edmonson RJ, Monaghan IM and Davies BR (2002) The human ovarian surface epithelium is an androgen responsive tissue British lournal of Cancer 86879 885

Elsaesser $F$ and Parvizi N (1979) Estrogen feedback in the pig: sexual differentiation and the effect of prenatal testosterone treatment Biology of Reproduction 20 1187-1193

Evans G, Dobias M, King GJ and Armstrong DT (1981) Estrogen, androgen and progesterone biosynthesis by theca and granulosa of preovulatory follicles in the pig Biology of Reproduction 25673.682

Fischer HE, Bazer FW and Fields MJ (1985) Steroid metabolism by endometrial and conceptus tissues during early pregnancy and pseudopregnancy in gilts Journal of Reproduction and Fertility 75 69-78

Fitko R, Jana B, Kucharski J and Sobezak J (1998) Changes 
in periestrous hormonal profile in blood of gilts with different thyroid function and ovarian cysts Polish lournal of Veterinary Science $13-9$

Ford J and Christenson RK (1987) Influences of preand postnatal testosterone treatment on defeminization of sexual receptivity in pigs Biology of Reproduction $36581-587$

Ford J and Howard HJ (1997) Activin inhibition of estradiol and progesterone production in porcine granulosa cells Journal of Animal Science 75 761-766

Foxcroft GR and Hunter MG (1985) Basic physiology of follicular maturation in the pig Journal of Reproduction and Fertility Supplement 33 1-19

Gadsby JE (1978) Oestrogen synthesis and steroid metabolism by blastocyst, embryonic and maternal tissues of the pig, cow and sheep during early pregnancy Ph. D. thesis, University of Cambridge

Garrett WM and Guthrie HD (1996) Expression of androgen receptors and steroidogenic enzymes in re lation to follicular growth and atresia following ovulation in pigs Biology of Reproduction 55 949-955

Gorczynska E and Handelsman DJ (1995) Androgens rapidly increase the cytosolic calcium concentrations in Sertoli cells Endocrinology 136 2052-2059

Gregoraszczuk EL and Oblonczyk K (1996) Effects of a specific aromatase inhibitor on oestradiol secretion by porcine corpora lutea at various stages of the luteal phase. Reprodution, Nutrition, Development 36 65-72

Grino PB, Griffin JE and Wilson JD (1990) Testosterone at high concentrations interacts with the human androgen receptor similarly to dihydrotestosterone Endocrinology 126 1165-1172

Guthrie HD and Bolt DJ (1990) Changes in plasma follicle-stimulating hormone, luteinizing hormone, estrogen and progesterone during growth of ovulatory follicles in the pig Domestic Animal Endocrinology 7:83-91

Guthrie HD, Garrett WM and Cooper BS (1998) Follicle-stimulating hormone and insulin-like growth factor-I attenuate apoptosis in cultured porcine granulosa cells Biology of Reproduction 58 390-396

Haning RV, Tantravahi U, Zhao Q, Hackett RJ and Canick JA (1996) $5 \alpha$-reductase 1 and 2 expression and activity in human ovarian follicles, stroma and corpus luteum as compared to neonatal foreskin journal of Steroid Biochemistry and Molecular Biology 59 199204

Henricks DM and Tindal DJ (1971) Metabolism of progesterone-4-[14 $\mathrm{C}]$ in porcine uterine endometrium Endocrinology 89 920-924

Herbison AE, Skinner DC, Robinson JE and King IS (1996) Androgen receptor-immunoreactive cells in ram hypothalamus: distribution and co-localization patterns with gonadotropin-releasing hormone, somatostatin and tyrosine hydroxylase Neuroendocrinology 63120-131

Herrick JR and Pope WF (2002) Exposure to androgens during in vitro maturation does not affect developmental potential of porcine oocytes Theriogenology $581131-1139$
Hickey GJ, Chen S, Besman MJ, Shively JE, Hall PF, Gaddy-Kurten D and Richards IS (1988) Hormonal regulation, tissue distribution, and content of aromatase cytochrome $\mathrm{P} 450$ messenger ribonucleic acid and enzyme in rat ovarian follicles and corpora lutea: Relationship to estradiol biosynthesis Endocrinology 122 1426-1436

Hickey TE, Marrocco DL, Gilchrist RB, Norman RJ and Armstrong DT (2004) Interactions between androgen and growth factors in granulosa cell subtypes of porcine antral follicles Biology of Reproduction 71:45. 52

Hillier SG and Tetsuka $M$ (1997) Role of androgens in follicle maturation and atresia Baillieres Clinical $O b$ stetrics and Cynaecology $11249-260$

Ito K, Suzuki T, Akahira J, Moriya T, Kaneko C, Utsunomiya H, Yaegashi N, Okamura K and Sasano $H$ (2002) Expression of androgen receptor and 5atpha-reductases in the human normal endometrium and its disorders International Journal of Cancer 99 $652-657$

Jana B, Kucharski J and Kotwica J (2000) Effect of unilateral, intraovarian infusions of Escherichia coli endotoxin on ovarian morphology and blood hormonal profiles in gilts Polish lournal of Veterinary Science 3 105-110

Jana B, Kucharski J and Ziecik AJ (2004) Effect of intrauterine infusion of Escherichia coli on hormonal patterns in gilts during the oestrous cycle Reproduction, Nutrition, Development $4437-48$

Jia XC, Kessel B, Welsh TH and Hsueh AJ (1985) Androgen inhibition of follicle-stimulating hormone- stimulated luteinizing hormone receptor formation in cultured rat granulosa cells Endocrinology 117 13-22

Johnson RK, Nielsen MK and Casey DS (1999) Responses in ovulation rate, embryonal survival, and litter traits in swine to 14 generations of selection to increase litter size fournal of Animal Science 77 541-557

Kaipia A and Hsueh AJW (1997) Regulation of ovarian follicle atresia Annual Review of Physiology 59 349363

Kim J, Jia L, Stallcup MR and Coetzee GA (2005) The role of protein kinase $A$ pathway and CAMP responsive element-binding protein in androgen receptormediated transcription at the prostate-specific antigen locus Journal of Molecular Endocrinology 34107. 118

LaBarbera AR and Ryan RJ (1981) Porcine granulosa cells in suspension culture. I. Follicle-stimulating hormone induction of human chorionic gonadotropin-binding sites on cells from small follicles Endocrinology 108 1561-1570

Labrie F, Luu-The V, Labrie C, Bélanger A, Simard J, Lin S$X$ and Pelletier G (2003) Endocrine and intracrine sources of androgens in women: inhibition of breast cancer and other roles of androgens and their precursor dehydroepiandrosterone Endocrine Reviews 24 152-182

Lephart FD, Doody KJ, McPhaul MJ and Simpson ER (1992) Inverse relationships between ovarian aromatase cytochrome $\mathrm{P} 450$ and $5 \alpha$-reductase en- 
zyme activities and mRNA activities during the estrous cycle in the rat Journal of Steroid Biochemistry and Molecular Biology 42 439-447

Liu J, Aronow BJ, Witte DP, Pope WF and La Barbera AR (1998) Cyclic and maturation-dependent regulation of follicle-stimulating hormone receptor and luteinizing hormone receptor messenger ribonucleic acid expression in the porcine ovary Biology of Reproduction 68 648-658

Marrow AL, Pace JR, Purdy RH and Paul SM (1990) Characterization of steroid interactions with $\gamma$ aminobutyric acid receptor-gated chloride ion channels: evidence of multiple steroid recognition sites Molecular Pharmacology 37 263-270

Martini L, Melcangi RC and Maggi R (1993) Androgen and progesterone metabolism in the central and peripheral nervous system The lournal of Steroid Biochemistry and Molecular Biology 47 195-205

McEwen BS (1976) Endocrine effects on the brain and their relationship to behavior Basic Neurochemistry Eds G) Siegel, RW Albers, R Katzman and BW Agranoff pp 737-764 Little Brown and Company, Boston

Nakano R, Akahori T, Katayama K and Tojo S (1977) Binding of $\mathrm{LH}$ and $\mathrm{FSH}$ to porcine granulosa cells during follicular maturation Journal of Reproduction and Fertility $11327-33$

Otala M, Makinen S, Tuuri T, Sjoberg J, Pentikainen V, Matikainen T and Dunkel L (2004) Effects of testosterone, dihydrotestosterone, and 17 B-estradiol on human ovarian tissue survival in culture fertility and Sterility 82 (Suppl 3) 1077-1085

Pak RC, Tsim KW and Cheng CH (1985) The role of neonatal and pubertal gonadal hormones in regulating the sex dependence of the hepatic microsomal testosterone 5-reductase activity in the rat lournal of Endocrinology 106 71-79

Payne DW, Packman JN and Adashi EY (1992) Folliclestimulating hormone inhibits granulosa cell $5 \alpha$-reductase activity lournal of Biological Chemistry 267 13348-13355

Peters $\mathbf{H}$ and MCNatty KP (1980) The ovary Granada Publishing. London

Petric N, Kato Y and Elsaesser F (2004) Influence of prenatal testosterone treatment on foetal and prepubertal LHß-subunit mRNA and plasma LH concentrations in the female pig Domestic Animal Endocrinology $2725-38$

Redmond GP (1998) Androgens and women's health International fournal of Fertility in Women's Medicine 43 91-97

Revelli A, Massobrio M and Tesarik J (1998) Nongenomic actions of steroid hormones in reproductive tissues Endocrine Reviews 19 3-17

Rohde Parfet KA, Lamberson WR, Rieke AR, Cantley TC, Ganjam VK, vom Saal FS and Day BN (1990) Intrauterine position effects in male and female swine: subsequent survivability, growth rate, morphology and semen characteristics Journal of Animal Science $68 \quad 179-185$

Roy AK and Chatterjee B (1995) Androgen Action Criti- cal Reviews in Eukaryotic Gene Expression 5 157.176

Sato T, Matsumoto T, Kawano $H$, Watanabe T, Uematsu Y, Sekine K, Fukuda T, Aihara K, Krust A, Yamada T, Nakamichi Y, Yamamoto Y, Nakamura T, Yoshimura K, Yoshizawa T, Metzger D, Chambon P and Kato S (2004) Brain masculinization requires androgen receptor function Proceedings of the National Academy of Sciences of the United States of America 101 16731678

Schreiber JR, Nakamura RK, Schmil V and Weinstein DB (1984) Androgen and FSH synergistically stimulate lipoprotein degradation and utilization by ovary granulosa cells Steroids $\mathbf{4 3}$ 25-42

Seifert JN, Larsen N\}, Marklund S, Hu ZL, Rohrer GA and Rothschild MF (1999) Genetic linkage and physical mapping of the porcine androgen receptor (AR) gene lournal of Animal Science 77 785-786

Shah NM, Pisapia DJ, Maniatis S, Mendelsohn MM, Nemes $A$ and Axel R (2004) Visualizing sexual dimorphism in the brain Neuron 43 313-319

Sheets CS, Aten RF, Kates RS, Preston PE and Eisenfeld A) (1985) Androgen receptor in the rabbit liver and apparent translocation to the nucleus in vivo Endocrinology 116 677-685

Sheng Z, Kawano J, Yanai A, Fujinaga R, Tanaka $M$, Watanabe $Y$ and Shinoda $K$ (2004) Expression of estrogen receptors $(\alpha, \beta)$ and androgen receptor in serotonin neurons of the rat and mouse dorsal raphe nuclei: sex and species differences Neuroscience Research 49 185-196

Slomczyñska $M$ and Tabarowski Z (2001) Localization of androgen receptor and cytochrome $\mathrm{P} 450$ aromatase in the follicle and corpus luteum of the porcine ovary Animal Reproduction Science 65 127-134

Stone BA and Seamark RF (1985) Steroid hormones in uterine washings and in plasma of gilts between days 9 and 15 after oestrus and between days 9 and 15 after coitus Journal of Reproduction and Fertility 75 209-221

Sullivan SD and Moenter SM (2004) GABAergic integration of progesterone and androgen feedback to gonadotropin-releasing hormone neurons Biology of Reproduction 72 33-41

Tetsuka M, Whitelaw PF, Bremmer WI, Millar MR, Smyth $C D$ and Hillier SG (1995) Developmental regulation of the androgen receptor in the rat ovary lournal of Endocrinology 145 535:543

Thornton J and Goy RW (1986) Female-typical sexual behavior of rhesus and defeminization by androgens given prenatally Hormone Behavior 20129 . 147

Torres JM and Ortega E (2003) Differential regulation of steroid 5 alpha-reductase isozymes expression by androgens in the adult rat brain The Federation of American Societies of Experimental Biology Journal 11 1428-1433

Trakooljul N, Ponsuksili S, Schellander $K$ and Wimmers $K$ (2004) Polymorphisms of the porcine androgen receptor gene affecting its amino acid sequence and expression level Biochemica et Biophysica Acta 1678 94-101 
Tsang BK, Ainsworth L, Downey BR and Marcus GJ (1985) Differential production of steroids by dispersing granulosa and theca interna cells from developing preovulatory follicles of pigs fournal of $R e$ production and Fertility 74 459-471

Vendola K, Zhou J, Wang J and Bondy CA (1999) Androgens promote insulin-like growth factor-I receptor gene expression in the primate ovary Biology of Reproduction 61 353-357

Waxman DJ, Morrissey II and Leblanc GA (1989) Female-predominant rat hepatic P-450 forms $\mathrm{j}$ (IIE 1) and 3 (IIA1) are under hormonal regulatory controls distinct from those of the sex-specific P-450 forms Endocrinology 124 2954-2966

Wilson JD (1975) Metabolism of testicular androgens. In Handbook of Physiology Section: Endocrinology Vol V Male Reproductive System, pp 491-508 Eds RO Greep and EB Astwood, Washington, DC: American Physiology Society

Wilson, J (1996) Androgens In Coodman and Cilman's The Pharmaceutical Basis of Therapeutics, $9^{\text {th }} \mathrm{Ed} \mathrm{Chap-}$ ter 58, pp 1441-1457 Eds JG Hardman, LE Limbird, PB Molinoff, RW Ruddon and A Goodman Gilman McGraw Hill Publishing Company, New York

Wilson JD and Russell DW (1994) Steroid $5 \alpha$-reductase: two genes/two enzymes Annual Reviews of Biochemistry 36 25-61

Wise T and Ford JJ (1998) Relationships of liver weight, cholesterol, albumin and $\alpha 2$-macroglobulin concentrations with ovarian function in swine lournal of Steroid Biochemistry and Molecular Biology 67 383390
Wise TH and Christenson RK (1992) Relationship of foetal position within the uterus to foetal weight, placental weight, testosterone, estrogens, and Thymosin B4 concentrations at 70 and 104 days of gestation in swine lournal of Animal Science 702787. 2793

Yates FE, Herbst AL and Urquhart I (1958) Sex differences in the rate of ring $A$ reduction of $\Delta^{4}-3$-ketosteroids in vitro by rat liver Endocrinology 63887 . 902

Yeh S, Tsai MY, Xu Q, Mu XM, Lardy H, Huang KE, Lin $H$, Yeh SD, Altuwaijri S, Zhou X, Xing L, Boyce BF, Hung MC, Zhang S, Gan L and Chang C (2002) Generation and characterization of androgen receptor knockout (ARKO) mice: An in vivo model for the study of androgen functions in selective tissues Proceedings of the National Academy of Sciences 99 13498-13503

Yen HW, Ford IJ, Zimmerman DR and Johnson RK (2005) Follicular development and maturation in gilts selected for an index of high ovulation rate and high prenatal survival Journal of Animal Science 83 130135

Zhang J, Sun Y, Lin Y, Sun Y and Liao DJ (2004) Synergistic effects of androgen and estrogen on the mouse uterus and mammary gland Oncology Reports 12 709.716 